\title{
Regional management practices and prevalence of bovine respiratory disease in California's preweaned dairy calves
}

\author{
B. M. Karle, ${ }^{1}$ G. U. Maier, ${ }^{2}$ W. J. Love, ${ }^{2 *}$ S. A. Dubrovsky, ${ }^{3}$ D. R. Williams, ${ }^{2}$ R. J. Anderson, ${ }^{4}$ \\ A. L. Van Eenennaam, ${ }^{3}$ T. W. Lehenbauer, ${ }^{2,5}$ and S. S. Aly ${ }^{2,5} \dagger$ \\ ${ }^{1}$ Cooperative Extension, Division of Agriculture and Natural Resources, University of California, Orland 95963 \\ ${ }^{2}$ Veterinary Medicine Teaching and Research Center, School of Veterinary Medicine, University of California, Davis, Tulare 93274 \\ ${ }^{3}$ Department of Animal Science, University of California, Davis 95616 \\ ${ }^{4}$ California Department of Food and Agriculture, Animal Health Branch, Modesto District, Modesto 95358 \\ ${ }^{5}$ Department of Population Health and Reproduction, School of Veterinary Medicine, University of California, Davis 95616
}

\section{ABSTRACT}

The objective of this cross-sectional study was to estimate the prevalence of bovine respiratory disease (BRD) in California preweaned dairy calves and identify management practices that are associated with BRD. A convenience sample of 100 dairies in the 3 distinct dairy regions of California was surveyed. Regions evaluated were Northern California (NCA), northern San Joaquin Valley (NSJV), and greater Southern California (GSCA). A questionnaire on calf management practices and demographic information was administered via in-person interviews at each dairy and a random sample of preweaned calves was evaluated using the California BRD scoring system on the same day. Prevalence of BRD varied between the 3 dairy regions: $9.30 \%$ in NCA, $4.51 \%$ in NSJV, and $7.35 \%$ in GSCA. Breed was not associated with BRD prevalence at the statewide level, but differences in prevalence were observed between breeds across the regions with a higher prevalence in NCA for Jerseys and in GSCA for Holsteins, compared with NSJV. Prevalence of BRD was not different between organic and conventional dairies. Colostrum management practices, including heat treatment and feeding colostrum from multiparous cows, varied by region and were associated with lower BRD prevalence. Calves housed in group pens, a practice observed primarily in NCA, had a higher BRD prevalence than those in individual housing. Feeding salable milk was also more common in NCA and was associated with lower BRD prevalence. Ground and road surfaces adjacent to the calf raising area were also variable by region, and paved surfaces were associated

Received March 20, 2018.

Accepted September 7, 2018.

${ }^{*}$ Current address: Department of Population Health and Pathobiology, College of Veterinary Medicine, North Carolina State University, Raleigh 27607.

†Corresponding author: saly@ucdavis.edu with lower BRD prevalence. Management practices associated with BRD varied across the state and may be addressed to inform the adoption and implementation of potentially protective management decisions on California dairies and other regions with similar dairy systems.

Key words: dairy calf, bovine respiratory disease, California

\section{INTRODUCTION}

Bovine respiratory disease (BRD) is one of the most important diseases affecting the health of dairy calves. It is a disease complex caused by multiple combinations of infectious agents and is typically presented as pneumonia or upper respiratory infections in all ages of cattle, particularly young stock. In a national survey of heifer raising facilities conducted by the National Animal Health Monitoring System (NAHMS), the highest cause-specific mortality was attributable to BRD in both preweaned and weaned dairy calves, with death losses of 2.3 and $1.3 \%$, respectively (USDA, 2012a). Respiratory disease affected $18.1 \%$ of preweaned calves across the nation according to the 2011 NAHMS Dairy Heifer Raiser study (USDA, 2012a), with $16.4 \%$ of calves being treated with antimicrobial drugs for BRD. Sawant et al. (2005) reported that pneumonia cases were responsible for $25 \%$ of antibiotic use in preweaned calves in a Pennsylvania study. Little progress has been made in reducing BRD rates in preweaned dairy calves, with the incidence changing little since the early 1990s and an increased proportion of preweaned calf deaths attributable to BRD (Gorden and Plummer, 2010).

The etiology of BRD is multifactorial, and the risk factors are complex and interconnected (Callan and Garry, 2002; Snowder, 2009; Murray et al., 2016b), making diagnosis challenging and, in turn, resulting in inconsistent treatment. Several different bacterial and viral pathogens contribute to BRD occurrence (Murray 
et al., 2016a), and consequently, no treatment measure has been proven to be completely effective (Fulton, 2009; Murray et al., 2016b). Given the wide range of factors that influence the prevalence of $\mathrm{BRD}$, a corresponding plethora of management practices also play a significant role in the likelihood that calves will be affected by the disease (Gorden and Plummer, 2010; Windeyer et al., 2017).

The California dairy industry is unique in its diversity, with 1.7 million dairy cows on 1,392 dairies (CDFA, 2017). Herd sizes across the state vary widely, ranging from a mean of 94 cows per dairy in a far northern county (Siskiyou) to a mean of 3,296 in Kern County in the Southern California area (CDFA, 2017). Management practices relative to herd size have been identified at a national level (USDA, 2010, 2012a); however, the categorical representation of herd size is not consistent with the range of dairy herd sizes in California. The USDA-NAHMS studies characterize "large" herds as those with 500 or more lactating cows, well below the mean California dairy herd size of 1,249 lactating cows (CDFA, 2017). Regional differences in size and management practices on dairies in California have been characterized previously (Meyer et al., 2006; Stull et al., 2008; Meyer et al., 2011; Love et al., 2016a), but a comparison has not been done of BRD prevalence as it relates to these differences. The objective of this crosssectional study was to estimate the prevalence of BRD in preweaned dairy calves and to identify and describe variations in management practices that may be associated with BRD throughout California. We hypothesized that there are differences in dairy management practices between regions of California as they relate to raising preweaned calves and that there are differences in $\mathrm{BRD}$ prevalence between dairies employing different management practices.

\section{MATERIALS AND METHODS}

\section{Sample Size Estimates}

Sample sizes for state prevalence and number of calves to be scored on the dairy was calculated with the formula

$$
n=\frac{N \times p \times(1-p)}{(N-1) \times\left(B^{2} / 4\right)+p \times(1-p)},
$$

where $n=$ number of dairies in the state or herd size (number of calves on the farm), $p=$ estimate of prevalence ( 0.5 for state prevalence, 0.25 for herd prevalence), and $B=$ magnitude of bound on the error of estimation of $P=0.1=2 \sqrt{\operatorname{Var}(\hat{p})}$ (Scheaffer et al., 2012).
Number of Herds. A sample size calculation for the number of dairies required to estimate the state prevalence of BRD in California yielded $\mathrm{n}=94$ with $\mathrm{n}=1,470$ dairies in the state in 2014 and assuming a conservative prevalence estimate of 0.5 , to maximize $n$.

Number of Calves. Within dairies, a simple random sample of calves was drawn to estimate the prevalence of BRD.

\section{Survey Tool}

Dairies in 3 geographic regions of California were surveyed in a cross-sectional study using a convenience sample between May 2014 and April 2016. The 3 distinct regions evaluated, as described in Love et al. (2016a), were Northern California (NCA; San Francisco area and counties to the north), northern San Joaquin Valley (NSJV; San Joaquin, Stanislaus, and Merced counties), and greater Southern California (GSCA; Fresno County and counties to the south, Figure 1). A comprehensive questionnaire that focused on calf management practices and relevant demographic information was administered via in-person interviews at each dairy. Questions asked referred to management practices as far back as when the oldest calf eligible to be enrolled was born. Section I of the questionnaire focused on dairy location, herd size, breeds, and organic or conventional production system. Section II questions inquired about calving management practices, including age at first calving, calving pen style and size, bedding management, and what percent of calves are removed from the dam within $1 \mathrm{~h}$. Section III questions covered colostrum management including colostrum source, use of colostrum replacer, heat treatment of colostrum, testing for bacteria content, colostrum storage practices (preservative, storage temperature, volume of storage, storage container), amount of colostrum from first calf heifers, testing colostrum for immunoglobulin content, volume fed within the first $12 \mathrm{~h}$, and if calves are tested for failure of transfer of passive immunity. Section IV focused on preweaned calf management including the calf herd size on site, housing style (group versus individual housing, calves per group, hutch type), whether calves from other dairies were raised on premises, age that calves were moved to group housing and weaned, and feeding order with regard to age and health status, if sick calves were moved to a hospital pen, if a specific scoring system was used to detect BRD, clinical signs used to identify BRD cases, and if BRD treatment decisions were based on a facility specific protocol. Section IV also detailed preweaned calf feeding programs to capture variations by age, breed, or sex that occurred on the dairy, including volume, source, pasteurization, testing for bacterial content, use of milk replacer 
or balancer, number of times fed daily, and if any supplemental medications were added to the milk or milk replacer. Section V included questions about vaccinations for preweaned calves and cows, and if calves were tested for bovine viral diarrheal virus persistent infection. Section VI inquired about dust management including type of driving surfaces near the calf raising area, if dust abatement practices were used, and how often dust was observed. In Section VII, the members of the study team evaluated the maternity pen, noting the degree of cover, size of enclosure, and hygiene score of 15 cows.

\section{Preweaned Calves' BRD Status}

Calves currently raised on each dairy were randomly sampled proportional to the calf herd size and evaluated using the California BRD scoring system, developed and validated by Love et al. (2014, 2016b; Table 1). The scoring system uses dichotomous, weighted visual signs to evaluate individual calves. A calf was assigned 2 points for each clinical sign: ocular discharge, spontaneous cough, rapid or difficult breathing, and rectal temperature of $39.2^{\circ} \mathrm{C}\left(102.5^{\circ} \mathrm{F}\right)$ or greater. Nasal discharge was assigned 4 points and ear droop or head tilt received 5 points. A calf was considered positive for BRD if its total score was equal to or greater than 5 . The random sample was drawn from all the calves in the preweaned calf housing area and included calves that were recently weaned on dairies that retained calves in individual hutches or pens postweaning. Ten evaluators conducted the surveys in person. New team members were trained on the California BRD scoring system and were accompanied at least once by an experienced team member on herd visits before conducting visits on their own to ensure consistency in data collection. The age, breed, sex, group size, potential for calf-to-calf contact, and distance to nearest dust source were recorded.

\section{Statistical Analyses}

The unit of analysis was dairy to estimate prevalence of the different management practices in the 3 dairy regions of California. However, the unit of analysis was calf to estimate prevalence of BRD. In addition, all estimates at the calf level were survey adjusted, where each observation was weighted by the inverse of the sampling fraction $\left(1 / f_{j}\right)$ with $f_{j}$ being the number of calves scored divided by the number of calves on the jth premises. Survey-adjusted prevalence was estimated using proportions for categorical variables and means for continuous variables. Variances were estimated using the jackknife procedure for survey adjusted data. Strata with single sampling units were omitted from

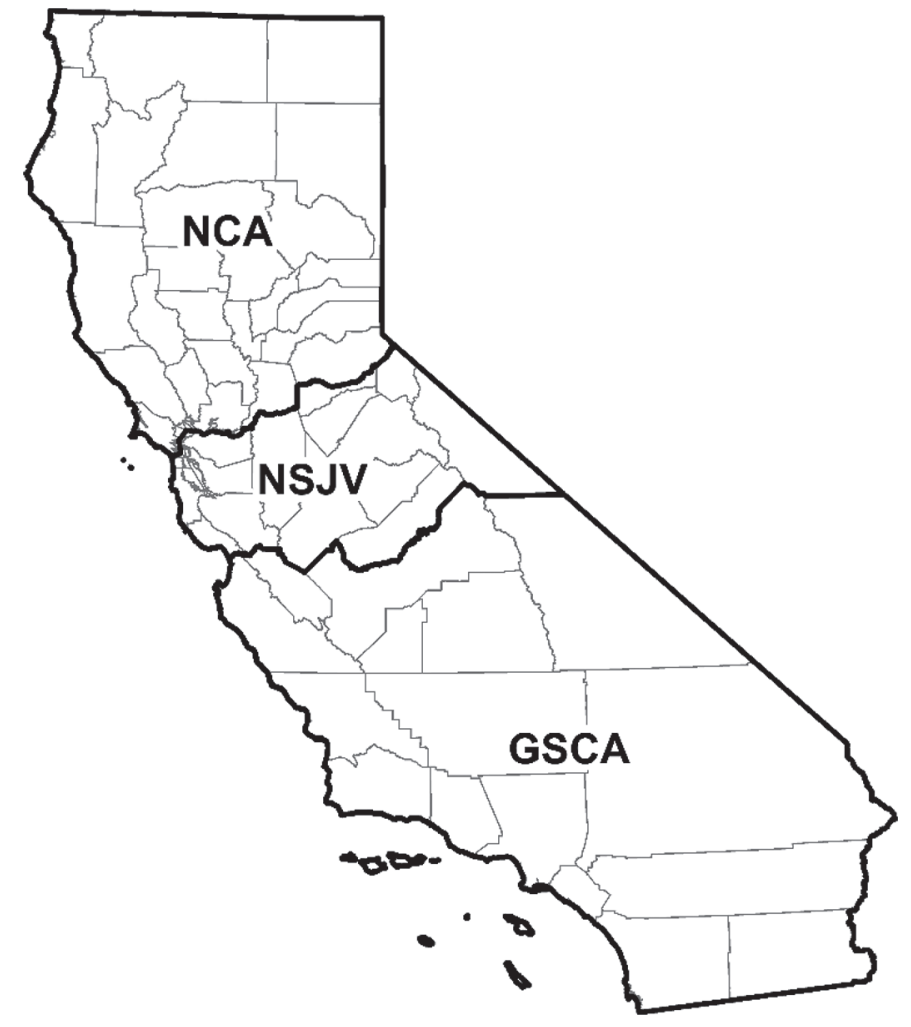

Figure 1. Map of counties in Northern California (NCA), northern San Joaquin Valley (NSJV), and greater Southern California (GSCA) regions for comparison of preweaned calf management practices and bovine respiratory disease prevalence.

proportion estimates because they prevented calculation of a standard error. Continuous variables were tested for normality with the Shapiro-Wilk test.

\section{RESULTS}

\section{Variables}

Herd size, age at first calving, number of bedding changes in the maternity pen, volume of colostrum fed in the first $12 \mathrm{~h}$ of life, and the number of calves per

Table 1. Clinical signs and weighted scores for the California bovine respiratory disease scoring system for preweaned dairy calves (Love et al., 2014)

\begin{tabular}{lc}
\hline Clinical sign & Score \\
\hline Ocular discharge & 2 \\
Nasal discharge & 4 \\
Ear droop or head tilt & 5 \\
Spontaneous cough & 2 \\
Rapid or difficult breathing & 2 \\
Rectal temperature $\geq 39.2^{\circ} \mathrm{C}\left(102.5^{\circ} \mathrm{F}\right)$ & 2
\end{tabular}

${ }^{1}$ Sum of scores $\geq 5$ may indicate that a calf is positive for bovine respiratory disease 
group for calves scored in group pens were not normally distributed. Hence, herd size was categorized based on perceived difference in management style into herds of $<250,250-999,1,000-3,999$, and $\geq 4,000$ milking cows. Age at first calving was dichotomized into above and below median of 24 mo. The number of times bedding in the maternity pen was changed per month was dichotomized into above and below 5 bedding changes per month based on histogram assessment. The volume of colostrum fed in first $12 \mathrm{~h}$ was dichotomized into $<2.84$ or $\geq 2.84 \mathrm{~L}$ (3 quarts) of colostrum as a relevant biological cut-point (Godden et al., 2009). The number of calves per group was categorized into individual calves, small groups (2-7), medium-sized groups (8-14), and large groups $(>14)$. Comparisons between levels of categorical variables were performed using $\chi^{2}$ tests. All post-hoc tests were performed using BonferroniDunn adjustments for multiple comparisons. Values of $P<0.05$ were considered statistically significant. All statistical analyses were performed using a commercial software package (Stata 14.2, Stata Corp., College Station, TX).

\section{Demographics}

A total of 104 dairies were surveyed and visited, with 100 herds (NCA, $\mathrm{n}=33$; NSJV, $\mathrm{n}=35$; GSCA, $\mathrm{n}=$ 32 ) and 4,636 calves (NCA, $\mathrm{n}=1,289 ; \mathrm{NSJV}, \mathrm{n}=$ 1,489; GSCA, $\mathrm{n}=1,858$ ) included in the final analyses. Age served as an indicator for the type of diet and vaccinations a calf had been subjected to at the time of the visit, and calves on 4 dairies with missing data on age could not be allocated to their respective groups. Preweaned calves scored on each dairy ranged in age from 0 to $182 \mathrm{~d}($ mean $=43.9 \mathrm{~d} \pm 0.43 ;$ median $=40$ $\mathrm{d}$, interquartile range: 20,64 ). The practice of weaning calves before moving to group pens was observed on some dairies in the study, resulting in records from 446 recently weaned calves that were included in our analysis. For the purposes of analysis of milk feeding management practices, these calves were excluded from the analysis. Herd size varied across the 3 different regions, with smaller herds in NCA (mean study herd size $679 \pm 137$ lactating cows), compared with a mean study herd size of $1,500 \pm 157$ in NSJV and 3,028 \pm 467 in GSCA.

Table 2 summarizes BRD prevalence differences by demographic characteristics. Prevalence of BRD varied between the 3 dairy regions (NCA $9.30 \pm 0.89 \%$, NSJV $4.51 \pm 0.70 \%$, GSCA $7.35 \pm 0.92 \% ; P=0.005)$. Calf breed was not associated with BRD prevalence at the statewide level $(P=0.49)$; however, differences in prevalence were observed between breeds across the regions with a higher prevalence in NCA for Jerseys compared with NSJV and GSCA $(P<0.001)$. Holsteins in GSCA had a higher BRD prevalence compared with NSJV but not compared with NCA $(P=0.015)$. Fewer Holsteins were present in NCA compared with GSCA $(P$ $=0.042)$ and more crossbred calves in NCA compared with both NSJV $(P=0.006)$ and GSCA $(P=0.043)$.

Prevalence of BRD was higher in large herds $(\geq 4,000$ cows, $10.70 \pm 1.66 \% ; P<0.001)$ compared with herds with 250 to 999 cows $(5.66 \pm 0.61 \%)$ and herds with 1,000 to 3,999 cows $(4.37 \pm 0.48 \%)$. Small herds in this study ( $<250$ cows) had higher BRD prevalence $(9.97 \pm$ $2.26 \%$ ) compared with herds with 1,000 to 3,999 cows, but not different from large herds $(\geq 4,000$ cows $)$ or those with 250 to 999 cows. Dairies in NCA were more likely to be certified organic ( 17 of the 33 dairies evaluated; $P<0.001)$ than in other parts of the state, with only 3 organic herds in NSJV of 35 evaluated, and 1 of the 32 herds evaluated in GSCA. Prevalence of BRD was not different in calves raised on organic dairies as compared with conventional dairies $(P=0.45)$.

Table 3 summarizes the geographic distribution of management practices that were significantly associated with reduced BRD prevalence. Details within each section are presented in the results that follow.

\section{Calving Management}

Mean age at first calving across all herds evaluated was $23.96 \pm 0.20$ mo. Herds in NCA calved at an older age of $24.72 \pm 0.36$ mo of age compared with $23.60 \pm$ $0.23 \mathrm{mo}$ in NSJV $(P=0.048)$ and $23.58 \pm 0.44 \mathrm{mo}$ in GSCA $(P=0.002)$. Prevalence of BRD in calves on dairies with a reported mean age at first calving of less than 24 mo of age was higher than those that calved at an older age $(P=0.002$; Table 4$)$.

The use of group, as opposed to individual, calving pens was common in all regions. Dairies in NSJV used group calving pens for $70.66 \pm 6.37 \%$ of first calf heifers, whereas herds in NCA and GSCA calved first calf heifers in group maternity pens more often (NCA 86.06 $\pm 5.78 \%$; GSCA $88.44 \pm 5.22 \% ; P=0.025)$. A similar trend was observed for multiparous cows, where 70.94 $\pm 6.54 \%$ calved in group pens in NSJV compared with $86.36 \pm 5.79 \%$ in $\mathrm{NCA}$ and $90.47 \pm 4.47 \%$ in GSCA $(P=0.060)$. Group versus individual calving pens was not associated with preweaned calf BRD prevalence (first calf heifers, $P=0.389$; multiparous cows, $P=$ 0.308; Table 4). The practice of calving first calf heifers and multiparous cows in the same enclosure, which was observed in all 3 regions, was also not associated with BRD prevalence $(P=0.118$; Table 4$)$. Pasture calving was only observed in NCA, with $30.3 \pm 8.12 \%$ of 
Table 2. Summary of bovine respiratory disease (BRD) prevalence in preweaned calves by demographic characteristics for 4,636 calves on 100 dairies in 3 regions of California (Northern California, NCA; northern San Joaquin Valley, NSJV; and greater Southern California, GSCA)

\begin{tabular}{|c|c|c|c|c|c|}
\hline \multirow[b]{2}{*}{ Factor } & \multirow[b]{2}{*}{$\mathrm{n}$} & \multirow{2}{*}{$\begin{array}{c}\text { Mean BRD } \\
\text { prevalence (\%) }\end{array}$} & \multirow[b]{2}{*}{ SEM } & \multicolumn{2}{|c|}{$95 \%$ CI } \\
\hline & & & & Lower & Upper \\
\hline \multicolumn{6}{|l|}{$\overline{\text { Region }}$} \\
\hline NCA & 1,289 & $9.30^{\mathrm{a}}$ & 0.89 & 7.70 & 11.20 \\
\hline NSJV & 1,489 & $4.51^{\mathrm{b}}$ & 0.70 & 3.32 & 6.10 \\
\hline GSCA & 1.858 & $7.35^{\mathrm{a}}$ & 0.92 & 5.74 & 9.37 \\
\hline \multicolumn{6}{|l|}{ Breed $^{1}$} \\
\hline Holstein (overall) & 3,239 & 7.21 & 0.81 & 5.77 & 8.98 \\
\hline NCA & 666 & $5.77^{\mathrm{ab}}$ & 1.11 & 3.94 & 8.38 \\
\hline NSJV & 1,082 & $4.69^{\mathrm{a}}$ & 0.83 & 3.30 & 6.62 \\
\hline GSCA & 1,491 & $7.98^{\mathrm{b}}$ & 1.06 & 6.14 & 10.33 \\
\hline Jersey (overall) & 1,083 & 5.68 & 0.70 & 4.46 & 7.21 \\
\hline NCA & 445 & $15.47^{\mathrm{a}}$ & 1.80 & 12.24 & 19.35 \\
\hline NSJV & 330 & $3.66^{\mathrm{b}}$ & 1.15 & 1.96 & 6.71 \\
\hline GSCA & 308 & $3.35^{\mathrm{b}}$ & 0.96 & 1.90 & 5.85 \\
\hline Other breeds (overall) & 304 & 5.72 & 2.68 & 2.23 & 13.88 \\
\hline NCA & 169 & $8.94^{\mathrm{a}}$ & 2.18 & 5.47 & 14.28 \\
\hline NSJV & 77 & $5.09^{\mathrm{a}}$ & 2.14 & 2.18 & 11.47 \\
\hline GSCA & 58 & $5.07^{\mathrm{a}}$ & 3.51 & 1.22 & 18.77 \\
\hline \multicolumn{6}{|l|}{ Herd size } \\
\hline$<250$ & 157 & $9.97^{\mathrm{ab}}$ & 2.26 & 6.30 & 15.41 \\
\hline $250-999$ & 1,539 & $5.66^{\mathrm{ac}}$ & 0.61 & 4.59 & 6.98 \\
\hline $1.000-3.999$ & 2,487 & $4.37^{\mathrm{c}}$ & 0.48 & 3.52 & 5.41 \\
\hline$\geq 4,000$ & 453 & $10.70^{\mathrm{b}}$ & 1.66 & 7.84 & 14.44 \\
\hline \multicolumn{6}{|l|}{ Organic status } \\
\hline Organic & 699 & $7.82^{\mathrm{a}}$ & 1.00 & 6.06 & 10.03 \\
\hline Conventional & 3,937 & $6.90^{\mathrm{a}}$ & 0.70 & 5.65 & 8.42 \\
\hline
\end{tabular}

${ }^{\mathrm{a}-\mathrm{c}}$ Means of a factor's levels with different superscripts are significantly different $(P<0.05)$.

${ }^{1}$ Does not include 10 calves that had missing information on breed.

herds utilizing any amount of pasture in the maternity area. No difference was observed in BRD prevalence for herds that included any amount of pasture compared with those dairies that did not use any pasture for the maternity pen $(P=0.40)$. However, closer examination revealed that calves born in pastures with no additional bedding had increased $\mathrm{BRD}$ prevalence compared with calves born in bedded maternity pens $(P<0.001$; Table 4). Most dairies $(84.85 \pm 6.34 \% \mathrm{NCA}, 65.71 \pm 8.14 \%$ NSJV, $78.13 \pm 7.42 \%$ GSCA) throughout the state changed or added bedding to the maternity pen 0 to 5 times monthly, whereas fewer dairies changed bedding more often (Table 3). Prevalence of BRD was lower on dairies with more frequent bedding changes, compared

Table 3. Regional comparison of frequency of reported herd level management practices that were significantly associated with reduced bovine respiratory disease prevalence on 100 dairies in 3 regions of California (Northern California, NCA; northern San Joaquin Valley, NSJV; and greater Southern California, GSCA)

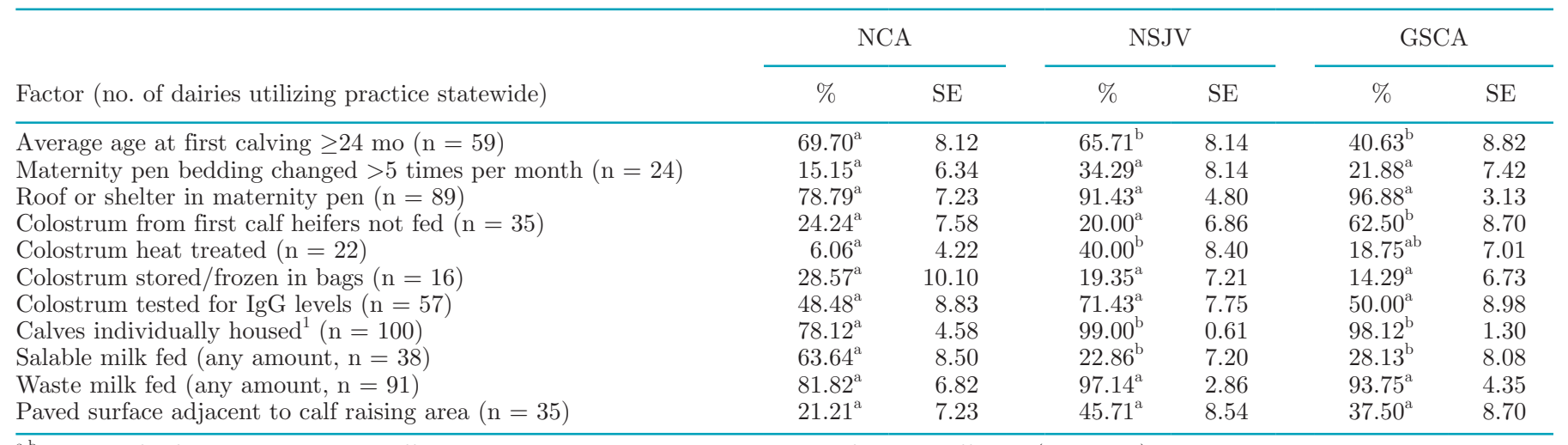

${ }^{\mathrm{a}, \mathrm{b}}$ Results of a factor's levels with different superscripts within a row are significantly different $(P<0.05)$.

${ }^{1}$ Mean of reported percentages of calves housed individually. All dairies housed at least some calves individually. 
with those that changed bedding 0 to 5 times monthly (Table 4). Dairies that used maternity pens with some type of roof or shelter had lower BRD prevalence than the 11 herds without any shelter $(P<0.001$; Tables 3 and 4). Most (NCA $81.82 \pm 6.82 \%$, NSJV $65.71 \pm$ $8.14 \%$, GSCA $65.63 \pm 8.53 \%$ ) of the herds in all regions left calves with the dam for longer than $1 \mathrm{~h}$ after calving $95 \%$ of the time, and BRD prevalence was not different compared with calves on dairies that typically removed calves from the dam within $1 \mathrm{~h}(\geq 95 \%$ calves removed within 1 h $7.35 \pm 1.12 \%$; $<95 \%$ calves removed within 1 h $6.51 \pm 0.78 \% ; P=0.531$ ).

\section{Colostrum Management}

Producer estimates of amount and source of colostrum fed indicated that herds in NCA were more likely to allow calves to nurse colostrum from the dam for the first colostrum feeding $(19.91 \pm 5.86 \%$ of colostrum fed) than herds in NSJV $(2.29 \pm 1.05 \%$ of colostrum fed) and GSCA $(1.28 \pm 0.87 \%$ of colostrum fed, $P<$ 0.001). Pooled colostrum was a greater fraction of first feeding colostrum sources in NSJV and GSCA (73.43 $\pm 6.42 \% \mathrm{NSJV}, 68.59 \pm 7.81 \%$ GSCA) than in NCA $(46.03 \pm 7.58 \%, P=0.012)$. The association between colostrum management practices and BRD prevalence is summarized in Table 5. Herds that fed colostrum specifically from the calf's dam, either by allowing the calf to nurse or by hand feeding, had a lower BRD prevalence compared with pooled colostrum or a mix of sources, including colostrum replacer $(P<0.001)$. Dairies in GSCA more frequently excluded colostrum harvested from first calf heifers for a calf's first meal $(P$ $<0.001$; Table 3 ), a practice that was associated with lower BRD prevalence $(P<0.001)$. Overall, 22 of the 100 herds in this study heat-treated colostrum (Table $3)$. A greater proportion of herds in NSJV heat-treated colostrum as compared with NCA $(P=0.003$; Table 3$)$. Dairies in GSCA were not statistically different than the other 2 regions, with $18.75 \pm 7.01 \%$ utilizing heattreatment practices for colostrum. This practice was associated with lower BRD prevalence compared with herds that did not heat-treat colostrum $(P=0.001$; Table 5).

Storing colostrum in bags in a refrigerator or freezer as opposed to a solid container, such as a bottle, was also associated with lower BRD prevalence $(P<0.001)$, as was testing colostrum for IgG levels $(P=0.035$; Table 5), which was common practice on over half of the dairies in this study, with no difference based on

Table 4. Summary of bovine respiratory disease (BRD) prevalence in preweaned calves by calving management practices for 4,636 calves on 100 dairies in California

\begin{tabular}{|c|c|c|c|c|c|}
\hline \multirow[b]{2}{*}{ Factor } & \multirow[b]{2}{*}{$\mathrm{n}$} & \multirow{2}{*}{$\begin{array}{c}\text { Mean BRD } \\
\text { prevalence (\%) }\end{array}$} & \multirow[b]{2}{*}{ SEM } & \multicolumn{2}{|c|}{$95 \% \mathrm{CI}$} \\
\hline & & & & Lower & Upper \\
\hline \multicolumn{6}{|l|}{ Age at first calving } \\
\hline$\leq 24 \mathrm{mo}$ & 2,093 & $8.49^{\mathrm{a}}$ & 1.07 & 6.61 & 10.83 \\
\hline$>24 \mathrm{mo}$ & 2,543 & $4.78^{\mathrm{b}}$ & 0.69 & 3.60 & 6.33 \\
\hline \multicolumn{6}{|l|}{ First calf heifers per pen } \\
\hline Group & 3,210 & $7.24^{\mathrm{a}}$ & 0.86 & 5.73 & 9.11 \\
\hline Individual & 495 & $5.49^{\mathrm{a}}$ & 0.99 & 3.84 & 7.81 \\
\hline Mix & 931 & $6.10^{\mathrm{a}}$ & 1.04 & 4.35 & 8.49 \\
\hline \multicolumn{6}{|l|}{ Multiparous cows per pen } \\
\hline Group & 3,378 & $7.28^{\mathrm{a}}$ & 0.85 & 5.79 & 9.12 \\
\hline Individual & 456 & $6.00^{\mathrm{a}}$ & 1.09 & 4.19 & 8.53 \\
\hline Mix & 802 & $5.61^{\mathrm{a}}$ & 1.07 & 3.84 & 8.12 \\
\hline \multicolumn{6}{|c|}{ Cows and heifers calve together } \\
\hline No & 1,737 & $7.68^{\mathrm{a}}$ & 1.03 & 5.89 & 9.96 \\
\hline Yes & 2,899 & $5.79^{\mathrm{a}}$ & 0.70 & 4.55 & 7.33 \\
\hline \multicolumn{6}{|c|}{ Bedding material in calving pen } \\
\hline Dry manure & 569 & $4.49^{\mathrm{a}}$ & 1.00 & 2.89 & 6.91 \\
\hline Sand or dirt & 203 & $9.40^{\mathrm{ab}}$ & 2.72 & 5.24 & 16.29 \\
\hline Plant-based & 3,408 & $7.14^{\mathrm{a}}$ & 0.78 & 5.75 & 8.83 \\
\hline Gypsum & 87 & $3.33^{\mathrm{ac}}$ & 1.89 & 1.06 & 9.97 \\
\hline Pasture only & 250 & $16.29^{\mathrm{b}}$ & 2.85 & 11.42 & 22.70 \\
\hline Pasture plus plant-based & 119 & $0.55^{\mathrm{c}}$ & 0.41 & 0.13 & 2.36 \\
\hline \multicolumn{6}{|l|}{ Bedding changes per month } \\
\hline $0-5$ times & 3,481 & $8.10^{\mathrm{a}}$ & 0.89 & 6.53 & 10.02 \\
\hline$>5$ times & 1,155 & $3.51^{\mathrm{b}}$ & 0.70 & 2.37 & 5.17 \\
\hline \multicolumn{6}{|c|}{ Maternity pen roof or shelter } \\
\hline Yes & 4,183 & $5.43^{\mathrm{a}}$ & 0.57 & 4.42 & 6.67 \\
\hline No & 453 & $14.98^{\mathrm{b}}$ & 3.09 & 9.87 & 22.10 \\
\hline
\end{tabular}

${ }^{a-c}$ Means of a factor's levels with different superscripts are significantly different $(P<0.05)$. 
region $(P=0.101$; Table 3$)$. Dairies in all regions of our study fed on average $>3.6 \mathrm{~L}$ (4 quarts) of colostrum within the first $12 \mathrm{~h}$ of life (NCA $3.69 \pm 0.31 \mathrm{~L}$, NSJV $3.70 \pm 0.12 \mathrm{~L}$, GSCA $3.98 \pm 0.22 \mathrm{~L} ; P=0.574)$. No difference in BRD prevalence at levels less than $2.8 \mathrm{~L}$ (3 quarts) compared with greater than or equal to $2.8 \mathrm{~L}$ within the first $12 \mathrm{~h}$ was observed $(P=0.813$; Table 5$)$. Calves in GSCA were more frequently tested for failure of transfer of passive immunity $(50.00 \pm 8.98 \%)$ than in NCA $(15.15 \pm 6.34 \%)$ or NSJV $(20.00 \pm 6.86 \% ; P=$ $0.003)$, though the practice was not associated with a difference in BRD prevalence in this study $(P=0.096)$.

\section{Preweaned Calf Housing}

In the current study, $78.12 \pm 4.58 \%$ of sampled calves in NCA were housed in individual hutches or pens, whereas individual housing was more common in the other 2 regions $(P<0.001$; Table 3$)$. Calves housed in groups ranged from 2 to 30 calves per pen and the median group size was 9 (interquartile range: 7,12 ). Prevalence of BRD across all ages of preweaned calves was lower in calves housed in individual pens (6.79 $\pm 0.69 \%)$ compared with those housed in group pens $(15.17 \pm 1.97 \%, P<0.001$; Figure 2$)$. The BRD preva- lence in preweaned calves significantly increased for group sizes of 8 or larger compared with calves housed individually $(P<0.001$; Table 6$)$. Calves in hutches or pens on the ground had a numerically higher BRD prevalence than calves in elevated hutches $(P=0.057$; Table 6 ). The NCA herds were less likely to have calves onsite that were born on other dairies $(3.03 \pm 3.03 \%)$ than herds in NSJV $(31.43 \pm 7.96 \%)$ and GSCA $(28.13$ $\pm 8.08 \%, P=0.008)$, though the practice was not associated with increased risk for BRD in this study $(P$ $=0.191 ;$ Table 6$)$.

Wooden calf hutches were more common in GSCA, housing $87.26 \pm 0.60 \%$ of the study calves in that region $(P<0.001)$, whereas hutch and pen types were more mixed in NCA and NSJV (Figure 3). The BRD prevalence for calves housed in wooden $(6.72 \pm 0.89 \%)$, metal $(5.74 \pm 1.16 \%)$, or plastic $(4.55 \pm 0.80 \%)$ sided pens or hutches was lower than for those housed in mixed material $(14.44 \pm 4.62 \%)$ or group pens (15.20 $\pm 2.01 \% ; P=0.006)$. However, BRD prevalence relative to housing materials varied by region. Prevalence of BRD for calves housed in hutches or pens made of metal, including wire, pipe, or sheet metal, was higher for calves in NCA compared with wooden hutches $(P$ $<0.001$; Figure 3). Furthermore, prevalence of BRD

Table 5. Summary of bovine respiratory disease (BRD) prevalence in preweaned calves by colostrum management practices for 4,636 calves on 100 dairies in California

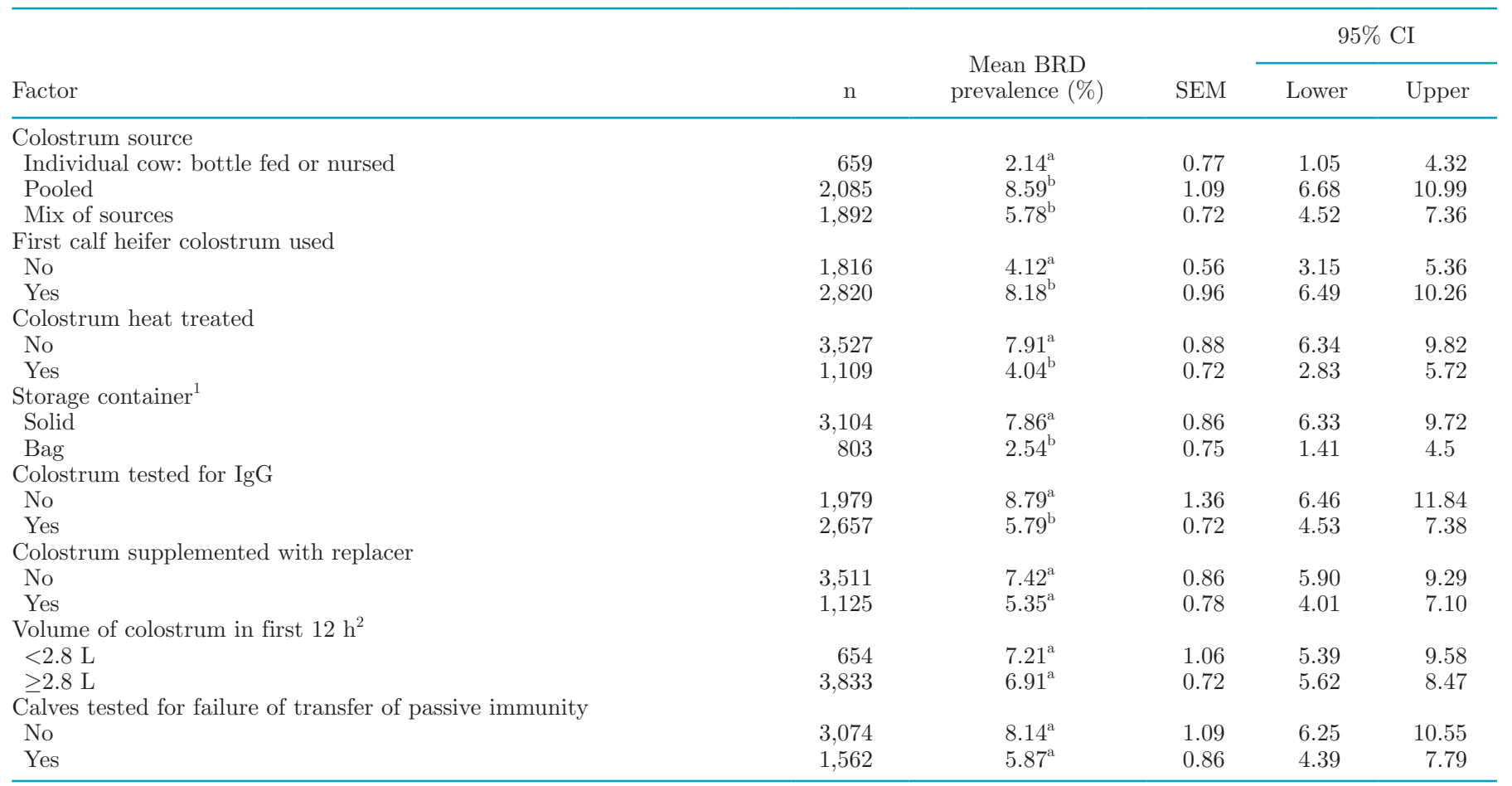

${ }^{\mathrm{a}, \mathrm{b}}$ Means of a factor's levels with different superscripts are significantly different $(P<0.05)$.

${ }^{1}$ For dairies that stored colostrum.

${ }^{2}$ For dairies that fed a known volume of colostrum (excludes colostrum nursed from dam). 


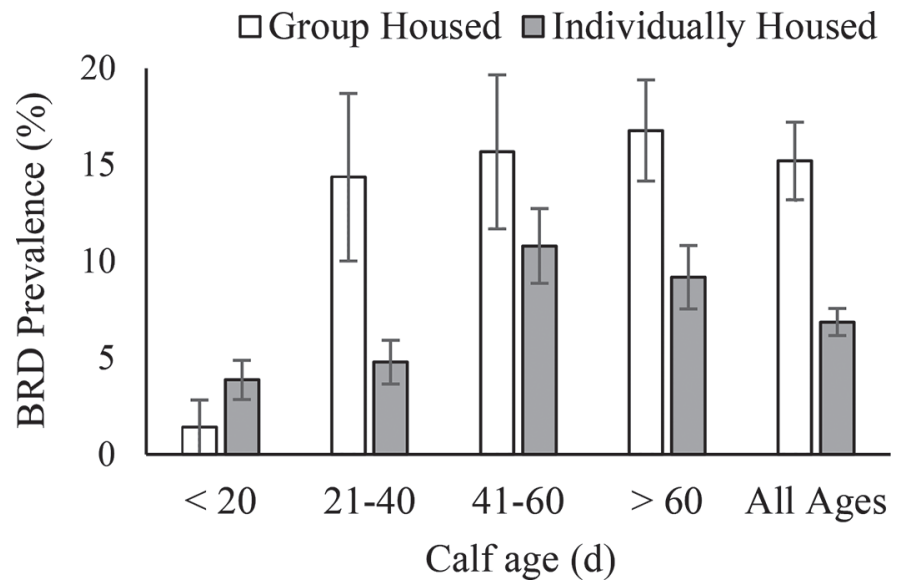

Figure 2. Prevalence of bovine respiratory disease (BRD) by calf age and housing system for calves on 100 dairies in California. Error bars indicate SE.

for calves in group pens in NCA $(24.07 \pm 3.18 \%)$ was higher compared with calves in wooden, plastic, or mixed material hutches or pens in the same region $(P$ $<0.001$ ). In GSCA, calves housed in hutches or pens made of mixed materials had higher BRD prevalence $(18.52 \pm 7.62 \%$; Figure 3$)$ compared with those housed in plastic hutches $(2.22 \pm 1.42 \%, P=0.028)$. In NSJV, housing materials were not associated with a difference in BRD prevalence $(P=0.071$; Figure 3$)$.

The NCA calves were weaned at $93 \pm 3.75 \mathrm{~d}$ of age, whereas calves in NSJV and GSCA were weaned at $76 \pm 3.33$ and $67 \pm 1.92 \mathrm{~d}$, respectively $(P<0.001)$.

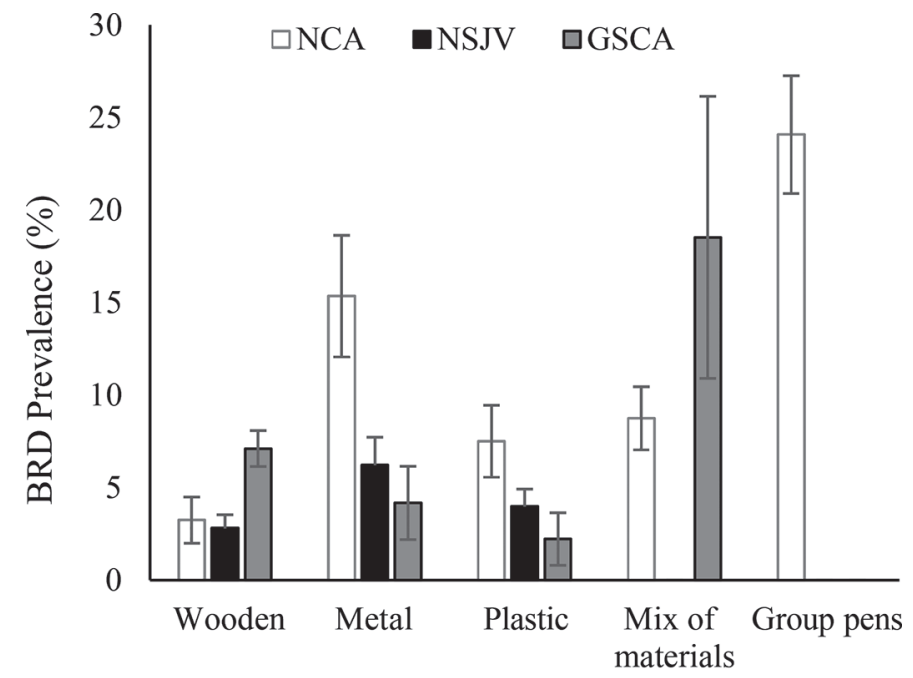

Hutch or Pen Materials

Figure 3. Prevalence of bovine respiratory disease (BRD) by housing materials for calves on 100 dairies in California by region: Northern California (NCA), northern San Joaquin Valley (NSJV), and greater Southern California (GSCA). Error bars indicate SE.

The age that calves were moved to group pens was not different between regions $(77 \pm 5.38 \mathrm{~d}$ NCA, $85 \pm 2.70$ d NSJV, $76 \pm 2.60 \mathrm{~d}$ GSCA; $P=0.200)$.

Feeding Management. Almost all herds (91\%) in this study fed some amount of waste milk to calves, whereas feeding salable milk was only common practice in $\mathrm{NCA}$, where $63.64 \pm 8.50 \%$ of the dairies fed it, compared with $22.86 \pm 7.20 \%$ in NSJV and $28.13 \pm$

Table 6. Summary of bovine respiratory disease (BRD) prevalence in preweaned calves by calf housing practices for 4,636 calves on 100 dairies in California

\begin{tabular}{|c|c|c|c|c|c|}
\hline \multirow[b]{2}{*}{ Factor } & \multirow[b]{2}{*}{$\mathrm{n}$} & \multirow{2}{*}{$\begin{array}{c}\text { Mean BRD } \\
\text { prevalence (\%) }\end{array}$} & \multirow[b]{2}{*}{ SEM } & \multicolumn{2}{|c|}{$95 \% \mathrm{CI}$} \\
\hline & & & & Lower & Upper \\
\hline \multicolumn{6}{|c|}{ Number of calves per group } \\
\hline 1 & 4,346 & $6.79^{\mathrm{a}}$ & 0.69 & 5.55 & 8.29 \\
\hline $2-7$ & 76 & $9.36^{\mathrm{ab}}$ & 3.29 & 4.54 & 18.31 \\
\hline $8-14$ & 88 & $15.54^{\mathrm{b}}$ & 2.99 & 10.47 & 22.44 \\
\hline$>14$ & 126 & $16.42^{\mathrm{b}}$ & 2.92 & 11.43 & 23.03 \\
\hline \multicolumn{6}{|c|}{ Hutch/pen elevation ${ }^{1}$} \\
\hline Elevated & 2,575 & $5.56^{\mathrm{a}}$ & 0.70 & 4.33 & 7.11 \\
\hline Not elevated & 1,245 & $7.30^{\mathrm{a}}$ & 0.85 & 5.79 & 9.16 \\
\hline \multicolumn{6}{|c|}{ Calves from other dairies } \\
\hline No & 3,630 & $7.62^{\mathrm{a}}$ & 0.91 & 6.01 & 9.61 \\
\hline Yes & 1,006 & $5.79^{\mathrm{a}}$ & 1.00 & 4.11 & 8.11 \\
\hline \multicolumn{6}{|l|}{ Hutch or pen type } \\
\hline Wooden & 2,350 & $6.72^{\mathrm{a}}$ & 0.89 & 5.18 & 8.68 \\
\hline Metal & 656 & $5.74^{\mathrm{a}}$ & 1.16 & 3.84 & 8.49 \\
\hline Plastic & 910 & $4.55^{\mathrm{a}}$ & 0.80 & 3.21 & 6.41 \\
\hline Mixed materials & 430 & $14.44^{\mathrm{b}}$ & 4.62 & 7.48 & 26.04 \\
\hline Group pens & 290 & $15.20^{\mathrm{b}}$ & 2.01 & 11.65 & 19.59 \\
\hline
\end{tabular}

${ }_{\mathrm{a}, \mathrm{b}}$ Means of a factor's levels with different superscripts are significantly different $(P<0.05)$.

${ }^{1}$ For dairies where hutch elevation was recorded. 
$8.08 \%$ in GSCA $(P=0.001$; Table 3$)$. Calves that were fed greater than $90 \%$ salable milk had significantly lower BRD prevalence as compared with those that were fed more than $90 \%$ medicated or nonmedicated milk replacer or a mix of sources $(P=0.003$; Table 7). Prevalence of BRD in calves fed waste milk was significantly lower than those that received a mix of sources $(P<0.001$; Table 7$)$. Pasteurizing milk before feeding was much more common in NSJV herds (71.43 $\pm 7.75 \%)$ and GSCA $(81.25 \pm 7.01 \%)$ compared with in NCA $(15.15 \pm 6.34 \% ; P<0.001)$ but was not significantly associated with BRD status $(P=0.051)$. Calves receiving more than $90 \%$ of the liquid diet consisting of milk or milk replacer containing antimicrobial drugs were not any more or less likely to score positive for BRD in the current study than those that did not receive antimicrobial drugs in the milk or milk replacer $(P=0.583$; Table 7$)$. Prevalence of BRD in herds that consistently fed the oldest calves first was higher compared with those with no particular feeding order and those that fed the youngest first $(P=0.047$; Table 7 ); however, no difference was observed between the groups after adjusting for multiple comparisons. More than two-thirds of dairies fed the youngest calves first $(66.67 \pm 8.33 \% \mathrm{NCA}, 80.00 \pm 6.86 \% \mathrm{NSJV}, 81.25 \pm$ $7.01 \%$ GSCA; $P=0.005)$.

Vaccinations. Most herds in our study $(\mathrm{n}=99)$ used vaccinations against respiratory disease pathogens in cows or calves. Vaccination protocols for calves were similar throughout the 3 regions, with more than $75 \%$ of herds using intranasal respiratory vaccines and just over half (58\%) utilizing injectable modified live respiratory vaccines $(\mathbf{M L V})$. Injectable killed respiratory vaccines (KV) for calves were used in 3 study herds that had a lower BRD prevalence as compared with the other 97 herds that did not use $\mathrm{KV}$ in calves $(P$ $<0.001$; Table 8). These 3 dairies did not additionally use an injectable MLV, but they did use intranasal respiratory vaccines in preweaned calves. Dairies in NCA tended to use fewer MLV in cows (48.48 $\pm 8.83 \%$ ) as compared with NSJV $(80.00 \pm 6.86 \%)$ and GSCA $(81.25 \pm 7.01 \% ; P=0.004)$ and the use of $\mathrm{KV}$ in cows was more common in NSJV (65.71 $\pm 8.14 \%)$ compared with NCA $(30.30 \pm 8.12 \%)$ and GSCA $(31.25 \pm 8.32 \%$; $P=0.003)$. We did not find associations between any other vaccination protocols and BRD prevalence in this study (Table 8).

Environment. Table 9 summarizes the associations between environmental factors and BRD prevalence. Herds in GSCA were more likely to house calves in environments with dirt road surfaces adjacent to the calf housing area $(46.88 \pm 8.96 \%)$ than in NCA $(12.12$ $\pm 5.77 \% ; P=0.008)$, where gravel was more commonly used $(69.70 \pm 8.12 \%)$. The GSCA dairies were subsequently more likely to use dust control practices $(84.38 \pm 6.52 \%)$ than dairies in NCA $(21.21 \pm 7.23 \%)$ or NSJV $(42.86 \pm 8.49 \% ; P<0.001)$. Paved surfaces were used on a minority of dairies in all 3 regions $(\mathrm{n}=$ $35 ; P=0.100$; Table 3 ) and were associated with lower BRD prevalence compared with nonpaved surfaces $(P$ $<0.001$; Table 9).

\section{DISCUSSION}

The 3 geographic regions in California were variable in both management practices and BRD prevalence.

Table 7. Summary of bovine respiratory disease (BRD) prevalence in preweaned calves by milk feeding practices for calves on 100 dairies in California

\begin{tabular}{|c|c|c|c|c|c|}
\hline \multirow[b]{2}{*}{ Factor } & \multirow[b]{2}{*}{$\mathrm{n}$} & \multirow{2}{*}{$\begin{array}{c}\text { Mean BRD } \\
\text { prevalence (\%) }\end{array}$} & \multirow[b]{2}{*}{ SEM } & \multicolumn{2}{|c|}{$95 \% \mathrm{CI}$} \\
\hline & & & & Lower & Upper \\
\hline \multicolumn{6}{|l|}{ Milk source (>90\% milk fed) } \\
\hline Salable milk & 459 & $2.42^{\mathrm{a}}$ & 0.91 & 1.15 & 5.02 \\
\hline Waste milk & 1,530 & $4.44^{\mathrm{ab}}$ & 0.70 & 3.24 & 6.04 \\
\hline Milk replacer (MR) & 242 & $8.19^{\mathrm{bc}}$ & 1.87 & 5.19 & 12.71 \\
\hline Mix of sources & 1,959 & $7.32^{\mathrm{c}}$ & 1.05 & 5.51 & 9.66 \\
\hline \multicolumn{6}{|l|}{ Pasteurization of milk } \\
\hline No & 1,716 & $8.09^{\mathrm{a}}$ & 0.81 & 6.64 & 9.83 \\
\hline Yes & 2,474 & $5.86^{\mathrm{a}}$ & 0.78 & 4.51 & 7.59 \\
\hline \multicolumn{6}{|c|}{ Antibiotics in $>90 \%$ milk or $\mathrm{MR}^{1}$} \\
\hline No & 3,110 & $6.50^{\mathrm{a}}$ & 0.82 & 5.07 & 8.31 \\
\hline Yes & 979 & $5.68^{\mathrm{a}}$ & 1.20 & 3.74 & 8.54 \\
\hline \multicolumn{6}{|l|}{ Feeding order } \\
\hline Youngest typically fed first & 3,123 & $5.47^{\mathrm{a}}$ & 0.67 & 4.29 & 6.95 \\
\hline No particular order & 792 & $5.38^{\mathrm{a}}$ & 0.74 & 4.09 & 7.04 \\
\hline Oldest typically first & 275 & $9.92^{\mathrm{a}}$ & 2.69 & 5.74 & 16.60 \\
\hline
\end{tabular}

${ }^{\mathrm{a}-\mathrm{c}}$ Means of a factor's levels with different superscripts are significantly different $(P<0.05)$.

${ }^{1}$ Excludes dairies where precise calf ages were not recorded. 
Table 8. Summary of bovine respiratory disease (BRD) prevalence in preweaned calves by respiratory vaccination strategies for 4,636 calves on 100 dairies in California

\begin{tabular}{|c|c|c|c|c|c|}
\hline \multirow[b]{2}{*}{ Factor } & \multirow[b]{2}{*}{$\mathrm{n}$} & \multirow{2}{*}{$\begin{array}{c}\text { Mean BRD } \\
\text { prevalence }(\%)\end{array}$} & \multirow[b]{2}{*}{ SEM } & \multicolumn{2}{|c|}{$95 \% \mathrm{CI}$} \\
\hline & & & & Lower & Upper \\
\hline \multicolumn{6}{|c|}{ Intranasal vaccines } \\
\hline \multicolumn{6}{|c|}{ Calves } \\
\hline No & 841 & $5.80^{\mathrm{a}}$ & 0.95 & 4.19 & 7.97 \\
\hline Yes & 3,795 & $7.03^{\mathrm{a}}$ & 0.74 & 5.71 & 8.62 \\
\hline \multicolumn{6}{|c|}{ Modified live vaccines } \\
\hline \multicolumn{6}{|c|}{ Calves } \\
\hline No & 1,754 & $6.70^{\mathrm{a}}$ & 1.15 & 4.78 & 9.33 \\
\hline Yes & 2,882 & $7.03^{\mathrm{a}}$ & 0.85 & 5.55 & 8.88 \\
\hline \multicolumn{6}{|l|}{ Cows } \\
\hline No & 1,291 & $7.40^{\mathrm{a}}$ & 0.79 & 5.99 & 9.10 \\
\hline Yes & 3,345 & $6.87^{\mathrm{a}}$ & 0.76 & 5.52 & 8.53 \\
\hline \multicolumn{6}{|c|}{ Killed vaccines ${ }^{1}$} \\
\hline \multicolumn{6}{|c|}{ Calves } \\
\hline No & 4,391 & $7.03^{\mathrm{a}}$ & 0.70 & 5.78 & 8.53 \\
\hline Yes & 142 & $1.55^{\mathrm{b}}$ & 0.65 & 0.67 & $\begin{array}{l}0.00 \\
3.52\end{array}$ \\
\hline \multicolumn{6}{|l|}{ Cows } \\
\hline No & 2,620 & $5.95^{\mathrm{a}}$ & 0.76 & 4.61 & 7.64 \\
\hline Yes & 2,016 & $8.36^{\mathrm{a}}$ & 1.26 & 6.21 & 11.18 \\
\hline
\end{tabular}

Mean herd size in our study was larger than the mean reported by California Department of Food and Agriculture (2017) for the year 2015 in each of the 3 regions (NCA 416 lactating cows/dairy, NSJV 1,234 lactating cows/dairy, GSCA 1,469 lactating cows/dairy). Calves on NSJV dairies had the lowest BRD prevalence, with a mean of $4.51 \%$ of calves affected at the time of our visit. Holsteins in GSCA and Jerseys in NCA had a higher prevalence than the other 2 regions. Organic and conventional dairies were not different in mean BRD prevalence; however, herd size was associated with higher prevalence in the smallest $(<250$ cows $)$ and largest herds ( $\geq 4,000$ cows) as compared with mid-size herds (1,000-3,999 cows).

Group calving pens were used by the majority of the study herds in all 3 regions with no associated difference in calves' BRD prevalence compared with those born in individual calving pens. Pithua et al. (2009) evaluated health outcomes for calves born in single or multiple cow pens and similarly found no significant association of calving pen type on levels of calf pneumonia. Pasture calving was only observed in NCA but was an interesting aspect of the current study. The highest BRD prevalence was found in calves born in

Table 9. Summary of bovine respiratory disease (BRD) prevalence in preweaned calves and environmental factors for 4,636 calves on 100 dairies in California

\begin{tabular}{|c|c|c|c|c|c|}
\hline \multirow[b]{2}{*}{ Factor } & \multirow[b]{2}{*}{$\mathrm{n}$} & \multirow{2}{*}{$\begin{array}{c}\text { Mean BRD } \\
\text { prevalence }(\%)\end{array}$} & \multirow[b]{2}{*}{$\mathrm{SE}$} & \multicolumn{2}{|c|}{$95 \% \mathrm{CI}$} \\
\hline & & & & Lower & Upper \\
\hline \multicolumn{6}{|c|}{ Road surfaces near calves } \\
\hline \multicolumn{6}{|l|}{ Paved } \\
\hline No & 2,917 & $8.40^{\mathrm{a}}$ & 0.93 & 6.75 & 10.41 \\
\hline Yes & 1,719 & $3.20^{\mathrm{b}}$ & 0.55 & 2.28 & 4.48 \\
\hline \multicolumn{6}{|c|}{ Gravel } \\
\hline No & 2,091 & $6.21^{\mathrm{a}}$ & 1.00 & 4.52 & 8.48 \\
\hline Yes & 2,545 & $7.33^{\mathrm{a}}$ & 0.91 & 5.74 & 9.32 \\
\hline \multicolumn{6}{|l|}{ Dirt } \\
\hline No & 3,230 & $7.80^{\mathrm{a}}$ & 0.98 & 6.08 & 9.96 \\
\hline Yes & 1,406 & $5.91^{\mathrm{a}}$ & 0.94 & 4.32 & 8.05 \\
\hline \multicolumn{6}{|c|}{ Dust abatement practices used } \\
\hline No & 2,163 & $5.96^{\mathrm{a}}$ & 0.97 & 4.32 & 8.17 \\
\hline Yes & 2,473 & $7.24^{\mathrm{a}}$ & 0.84 & 5.75 & 9.08 \\
\hline
\end{tabular}

${ }^{\mathrm{a}, \mathrm{b}}$ Means of a factor's levels with different superscripts are significantly different $(P<0.05)$. 
pastures without additional bedding whereas calves born in pastures with additional bedding had the lowest BRD prevalence rates. More research is needed to evaluate if a calving environment that includes pasture is associated with future calf health, especially in NCA herds where the practice is widespread. Most herds did not change maternity pen bedding more than 5 times per month, but the practice was associated with lower BRD prevalence and warrants further investigation as it may relate to BRD in preweaned calves.

Calves in our study that were fed heat-treated colostrum, colostrum from multiparous cows and colostrum that had been tested for IgG levels had a lower BRD prevalence. Dairies in GSCA were more likely to not feed colostrum from first-calf heifers compared with the 2 other regions. In a study conducted by Johnson et al. (2007), calves fed heat-treated colostrum had improved serum total protein, IgG concentration, and apparent efficiency of IgG absorption compared with calves that were fed raw colostrum. Immunoglobulin levels in colostrum were predictive of calf health in several studies (Wells et al., 1996; Virtala et al., 1999; Jaster, 2005; Williams et al., 2014) and producers are advised to test colostrum quality before feeding. Windeyer et al. (2014) suggested that serum total protein levels below $5.7 \mathrm{~g} / \mathrm{dL}$ were most predictive of BRD in young calves, emphasizing the importance of quality and quantity of colostrum. Extensive research emphasizes the importance of colostrum to a calf's future health status (Virtala et al., 1999; Callan and Garry, 2002; Beam et al., 2009; Windeyer et al., 2017), yet volume of colostrum fed was not significantly associated with BRD status in the current study. The lack of a significant association between volume of colostrum fed and BRD may be a result of the cross-sectional study design, use of a convenience sample of dairies, utilizing producer reported values for colostrum volume fed to calves, and how the colostrum was harvested and stored before feeding to calves. Our selected cutoff value $(2.8 \mathrm{~L})$ was similar to that evaluated by Godden et al. (2009), although the previous study was a controlled trial with 2 levels of colostrum evaluated (1.5 vs. $3 \mathrm{~L}$ ), whereas our study recorded producer reported volume of colostrum fed on a continuous scale. Evaluating colostrum fed immediately after birth or within a shorter period $(1 \mathrm{~h}$ or within 6 h) may have produced different results. Alternatively, the variability between dairies in our study may have not been enough to demonstrate a difference in health outcome by amount of colostrum fed. The practice of excluding first calf heifer colostrum was associated with lower BRD prevalence in this study, and others have reported that later lactation cows tend to produce higher quality colostrum (Morin et al., 2001; Chigerwe et al., 2009; Lombard et al., 2016).
Only dairies in the NCA region fed significant amounts of salable milk to preweaned calves, which was associated with decreased BRD prevalence. Feeding salable milk is a widespread practice in NCA, as certified organic dairies are concentrated in the region. Approved organic milk replacers are not widely available and conventional milk replacers are not permitted per the National Organic Program regulations (USDA, 2012b), necessitating the use of raw milk for calf feeding. Further research is needed to study the cost-effectiveness of including salable milk in calf feeding programs as a strategy to reduce BRD. In our study, pasteurization was not significantly associated with BRD; however, BRD prevalence was numerically lower in calves that consumed pasteurized milk compared with those that did not. In a multivariable model developed with the same data set, feeding pasteurized milk was negatively associated with BRD (Maier et al., 2019). Pasteurized waste milk has been shown to increase growth rate and decrease morbidity and mortality in dairy calves as compared with $20 \%$ protein and $20 \%$ fat formulated milk replacer (Godden et al., 2005). Similarly, reduction of bacteria in raw milk reduces calves' exposure to pathogens that may cause respiratory disease (Pfutzner and Sachse, 1996; Walz et al., 1997; Armengol and Fraile, 2016).

Group housing of calves was only common in NCA and was associated with higher rates of BRD compared with individual calf housing. Although it has been suggested that successful group housing of preweaned calves is possible (Reed et al., 1999; Bjorklund et al., 2013), others maintain that calves should be housed individually for optimal health outcomes (Svensson et al., 2003; Lorenz et al., 2011). Data from the current study indicate that further research on group housing practices is needed to identify areas of improvement that may reduce BRD occurrence.

Calves in NCA that were individually housed in hutches or pens made of primarily metal materials had a higher BRD prevalence than those in wooden hutches. Some of the materials used in metal pens, including wire or pipe, did not provide solid barriers between calves. Lago et al. (2006) identified that nonsolid pen dividers were associated with increased BRD in naturally ventilated calf barns in Wisconsin. The authors suggested that solid dividers would likely reduce the exchange of airborne pathogens and prevent nose-to-nose contact between calves, potentially reducing the risk of BRD (Lago et al., 2006). A longitudinal study of 11,300 preweaned calves in California showed that calves housed in hutches made of a combination of wood and metal were at higher risk of BRD compared with herd mates housed in hutches made of wood only (Dubrovsky et al., 2019). The current study was not 
designed to delineate differences in calf housing at this level and future research that explores housing materials using empirical study designs could be informative. Dairies in GSCA tended to be larger than those in the other 2 regions and typically raised calves in wooden "California-style" elevated hutches in environments that warranted more dust abatement than the other regions. The individual housing arrangements, typical of the NSJV and GSCA regions, were associated with lower BRD prevalence compared with housing in groups, which was more common in NCA.

Vaccination protocols showed little association with BRD status in the current study; however, the widespread use of vaccines in the study herds may have left little variability for comparison. Also, the current study did not capture information on vaccination protocols in the weaned calf and replacement heifer populations. Calves in herds that received killed vaccines did have an associated lower BRD prevalence in this study, but these results should be interpreted with caution given that this category was made up of calves in only 3 herds. Of these 3 herds, 1 had $<1 \%$ BRD prevalence and employed several management practices that were associated with lower BRD prevalence, especially as related to housing and feeding practices. The lower BRD prevalence is likely a result of several interconnected management practices rather than solely the type of vaccine used. Results of previous studies related to vaccination protocols to prevent BRD have been mixed. In a small study, Hill et al. (2012) found intranasal vaccination to be effective for young calves, and Makoschey et al. (2012) demonstrated improved protection against Mannheimia haemolytica from the colostrum of cows vaccinated with a killed vaccine at dry off. In a review of the literature, Ellis (2017) reported variable efficacy of vaccines against bovine respiratory syncytial virus. The authors evaluated challenge and long-term field studies and suggest that determination of efficacy is at least partially dependent upon the expectation of disease reduction as opposed to sterile immunity. Ellis (2017) additionally states that although intranasal bovine respiratory syncytial virus vaccines do provide some immunity in the face of maternal antibodies, the duration of immunity is relatively short. Others have suggested that evidence of vaccine efficacy seems to be lacking or unclear (Lorenz et al., 2011) and that blanket vaccination provides inconsistent control of BRD pathogens (Murray et al., 2016b). Windeyer et al. $(2012,2015)$ report that vaccination of preweaned calves did not reduce BRD, possibly due to herd immunity, vaccine timing, or the probability that the BRDcausing pathogens were outside of the spectrum covered by the vaccine. Future studies should evaluate the use of a variety of vaccine protocols in a more controlled environment to draw more specific conclusions about the effect of vaccines on BRD in preweaned calves.

A limitation of the current study was the lack of consistency in data collection across seasons. Dairies in each region were sampled during all 4 seasons, but the cross-sectional nature of this study does not provide the opportunity to evaluate the potential of a seasonal effect. In our experience, California's moderate climate seems to pose less of a challenge to animal health than shorter-term diurnal temperature fluctuations. This effect should be evaluated in future studies.

\section{CONCLUSIONS}

A variety of management factors are associated with BRD prevalence in preweaned dairy calves, which further emphasizes that BRD is multi-factorial and complex. Prevalence of BRD in California's preweaned dairy calves varied by breed, region, and management. Regional differences in management practices highlight extension and outreach opportunities to educate calf raisers in other parts of the state about potentially beneficial control and prevention measures to improve the respiratory disease status of their preweaned calf herds. Producers in NCA tended to calve first calf heifers at older ages, fed salable and waste milk, and calved cows on pastures with additional bedding, practices that were all associated with lower BRD prevalence. Group housing of preweaned calves may be an area for improvement in NCA as it was associated with increased prevalence of BRD. Herds in NSJV were more likely to heat treat colostrum and GSCA herds were more likely to exclude first calf heifer colostrum for a calf's first meal, both practices that were associated with lower prevalence of BRD. Furthermore, longitudinal studies at the calf and herd level will be useful to identify additional management practices that affect prevalence of respiratory disease in preweaned dairy calves. Data presented in the current study underscore the complexity of $\mathrm{BRD}$, the variability across geographic regions, and the importance of a multitude of management practices at the individual and herd level.

\section{ACKNOWLEDGMENTS}

Funding for this study was provided by competitive grant \#1753 "Risk assessment, welfare analysis, and extension education for dairy calf respiratory disease management in California," Sharif Aly (principal investigator), the University of California Division of Agriculture and Natural Resources, and the USDA National Institute of Food and Agriculture, Animal Health project CALV-AH-360. The authors acknowledge technical assistance by Jeffery Stackhouse (Coop- 
erative Extension, Division of Agriculture and Natural Resources, University of California, Ferndale), Nyles Peterson (Cooperative Extension, Division of Agriculture and Natural Resources, University of California, San Bernardino), Paul Rossitto, Courtney Faria, and Arianna Villarrreal (Veterinary Medicine Teaching and Research Center, School of Veterinary Medicine, University of California, Davis, Tulare), and participation by veterinary practitioners, the cooperating dairy owners, and calf caretakers.

\section{REFERENCES}

Armengol, R., and L. Fraile. 2016. Colostrum and milk pasteurization improve health status and decrease mortality in neonatal calves receiving appropriate colostrum ingestion. J. Dairy Sci. 99:4718 4725 .

Beam, A. L., J. E. Lombard, C. A. Kopral, L. P. Garber, A. L. Winter, J. A. Hicks, and J. L. Schlater. 2009. Prevalence of failure of passive transfer of immunity in newborn heifer calves and associated management practices on US dairy operations. J. Dairy Sci. 92:3973-3980.

Bjorklund, E. A., B. J. Heins, and H. Chester-Jones. 2013. Whole-milk feeding duration, calf growth, and profitability of group-fed calves in an organic production system. J. Dairy Sci. 96:7363-7370.

Callan, R. J., and F. B. Garry. 2002. Biosecurity and bovine respiratory disease. Vet. Clin. North Am. Food Anim. Pract. 18:57-77.

CDFA (California Department of Food and Agriculture). 2017. California Dairy Statistics Annual 2016. Sacramento, CA. Accessed Aug. 29, 2017. https://www.cdfa.ca.gov/dairy/pdf/Annual/2016/ 2016_Statistics_Annual.pdf.

Chigerwe, M., J. W. Tyler, M. K. Summers, J. R. Middleton, L. G. Schultz, and D. W. Nagy. 2009. Evaluation of factors affecting serum IgG concentrations in bottle-fed calves. J. Am. Vet. Med. Assoc. 234:785-789.

Dubrovsky, S. A., A. E. Van Eenennaam, B. M. Karle, P. V. Rossitto, T. W. Lehenbauer, and S. S. Aly. 2019. Epidemiology of bovine respiratory disease (BRD) in preweaned calves on California dairies: The BRD 10K study. J. Dairy Sci. 102:7306-7319. https://doi .org/10.3168/jds.2018-14774.

Ellis, J. A. 2017. How efficacious are vaccines against bovine respiratory syncytial virus in cattle? Vet. Microbiol. 206:59-68.

Fulton, R. W. 2009. Bovine respiratory disease research (1983-2009). Anim. Health Res. Rev. 10:131-139.

Godden, S. M., J. P. Fetrow, J. M. Feirtag, L. R. Green, and S. J. Wells. 2005. Economic analysis of feeding pasteurized nonsaleable milk versus conventional milk replacer to dairy calves. J. Am. Vet. Med. Assoc. 226:1547-1554.

Godden, S. M., D. M. Haines, K. Konkol, and J. Peterson. 2009. Improving passive transfer of immunoglobulins in calves. II: Interaction between feeding method and volume of colostrum fed. J. Dairy Sci. 92:1758-1764.

Gorden, P. J., and P. Plummer. 2010. Control, management, and prevention of bovine respiratory disease in dairy calves and cows. Vet. Clin. North Am. Food Anim. Pract. 26:243-259.

Hill, K. L., B. D. Hunsaker, H. G. Townsend, and P. J. Griebel. 2012. Mucosal immune response in newborn Holstein calves that had maternally derived antibodies and were vaccinated with an intranasal multivalent modified-live virus vaccine. J. Am. Vet. Med. Assoc. 240:1231-1240.

Jaster, E. H. 2005. Evaluation of quality, quantity, and timing of colostrum feeding on immunoglobulin $\mathrm{G}_{1}$ absorption in Jersey calves. J. Dairy Sci. 88:296-302.

Johnson, J. L., S. M. Godden, T. Molitor, T. Ames, and D. Hagman. 2007. Effects of feeding heat-treated colostrum on passive transfer of immune and nutritional parameters in neonatal dairy calves. J. Dairy Sci. 90:5189-5198.
Lago, A., S. M. McGuirk, T. B. Bennett, N. B. Cook, and K. V. Norlund. 2006. Calf respiratory disease and pen microenvironments in naturally ventilated calf barns in Winter. J. Dairy Sci. 89:4014-4025.

Lombard, J. E., C. B. Shivley, and N. Urie. 2016. Factors associated with colostrum quality and passive transfer status of dairy heifer calves on US dairy operations. J. Anim. Sci. 94(Suppl 5):592-592.

Lorenz, I., J. F. Mee, B. Earley, and S. J. More. 2011. Calf health from birth to weaning. I. General aspects of disease prevention. Ir. Vet. J. 64:10. https://doi.org/10.1186/2046-0481-64-10.

Love, W. J., T. W. Lehenbauer, B. M. Karle, L. E. Hulbert, R. J. Anderson, A. L. Van Eenennaam, T. B. Farver, and S. S. Aly. 2016a. Survey of management practices related to bovine respiratory disease in preweaned calves on California dairies. J. Dairy Sci. 99:1483-1494.

Love, W. J., T. W. Lehenbauer, P. H. Kass, A. L. Van Eenennaam, and S. S. Aly. 2014. Development of a novel clinical scoring system for on-farm diagnosis of bovine respiratory disease in preweaned dairy calves. PeerJ 2:e238.

Love, W. J., T. W. Lehenbauer, A. L. Van Eenennaam, C. M. Drake, P. H. Kass, T. B. Farver, and S. S. Aly. 2016b. Sensitivity and specificity of on-farm scoring systems and nasal culture to detect bovine respiratory disease complex in preweaned dairy calves. J. Vet. Diagn. Invest. 28:119-128.

Maier, G. U., W. J. Love, B. M. Karle, S. A. Dubrovsky, D. R. Williams, J. D. Champagne, R. J. Anderson, J. D. Rowe, T. W. Lehenbauer, A. L. V. Eenennaam, and S. S. Aly. 2019. Management factors associated with bovine respiratory disease in preweaning calves on California dairies: The BRD 100 study. J. Dairy Sci. 102:7288-7305. https://doi.org/10.3168/jds.2018-14773.

Makoschey, B., C. Ramage, D. Reddick, S. Fraser, and W. Donachie. 2012. Colostrum from cattle immunized with a vaccine based on iron regulated proteins of Mannheimia haemolytica confers partial protection. Vaccine 30:969-973.

Meyer, D., P. L. Price, H. A. Rossow, N. Silva-del-Rio, B. M. Karle, P. H. Robinson, E. J. DePeters, and J. G. Fadel. 2011. Survey of dairy housing and manure management practices in California. J. Dairy Sci. 94:4744-4750.

Meyer, D., B. Reed, C. Batchelder, I. Zallo, P. L. Ristow, G. Higginbotham, M. Arana, T. Shultz, D. D. Mullinax, and J. Merriam. 2006. Water use and winter liquid storage needs at Central Valley dairy farms in California. Appl. Eng. Agric. 22:121-126.

Morin, D. E., P. D. Constable, F. P. Maunsell, and G. C. McCoy. 2001. Factors associated with colostral specific gravity in dairy cows. J. Dairy Sci. 84:937-943.

Murray, G. M., R. G. O'Neill, S. J. More, M. C. McElroy, B. Earley, and J. P. Cassidy. 2016a. Evolving views on bovine respiratory disease: An appraisal of selected pathogens-Part 1. Vet. J. 217:95-102.

Murray, G. M., R. G. O'Neill, S. J. More, M. C. McElroy, B. Earley, and J. P. Cassidy. 2016b. Evolving views on bovine respiratory disease: An appraisal of selected control measures-Part 2. Vet. J. 217:78-82.

Pfutzner, H., and K. Sachse. 1996. Mycoplasma bovis as an agent of mastitis, pneumonia, arthritis and genital disorders in cattle. Rev. Sci. Tech. 15:1477-1494.

Pithua, P., S. J. Wells, S. M. Godden, and E. A. Raizman. 2009. Clinical trial on type of calving pen and the risk of disease in Holstein calves during the first 90d of life. Prev. Vet. Med. 89:8-15.

Reed, B., C. Stull, S. Berry, and C. Batchelder. 1999. Rearing immunodeficient calves on pasture reduces death, production costs. Calif. Agric. 53:35-40.

Sawant, A. A., L. M. Sordillo, and B. M. Jayarao. 2005. A survey on antibiotic usage in dairy herds in Pennsylvania. J. Dairy Sci. 88:2991-2999.

Scheaffer, R. L., W. Mendenhall, R. L. Ott, and K. G. Gerow. 2012. Elementary Survey Sampling. 7th ed. Brooks/Cole, Boston, MA.

Snowder, G. 2009. Genetics, environment and bovine respiratory disease. Anim. Health Res. Rev. 10:117-119.

Stull, C. L., L. M. Messam, C. A. Collar, N. G. Peterson, A. R. Castillo, B. A. Reed, K. L. Andersen, and W. R. VerBoort. 2008. Pre- 
cipitation and temperature effects on mortality and lactation parameters of dairy cattle in California. J. Dairy Sci. 91:4579-4591.

Svensson, C., K. Lundborg, U. Emanuelson, and S. O. Olsson. 2003. Morbidity in Swedish dairy calves from birth to 90 days of age and individual calf-level risk factors for infectious diseases. Prev. Vet. Med. 58:179-197.

USDA. 2010. Dairy 2007, Heifer Calf Health and Management Practices on U.S. Dairy Operations, 2007 USDA:APHIS:VS, CEAH Fort Collins, CO \#550.0110.

USDA. 2012a. Dairy Heifer Raiser, 2011 USDA-APHIS-VS, CEAH, National Animal Health Monitoring System (NAHMS), Fort Collins, CO \#613.1012.

USDA. 2012b. National Organic Program. United States Department of Agriculture, Agricultural Marketing Service. Accessed Dec. 15, 2017. http://www.ams.usda.gov/AMSv1.0/nop.

Virtala, A. M., Y. T. Gröhn, G. D. Mechor, and H. N. Erb. 1999 The effect of maternally derived immunoglobulin $\mathrm{G}$ on the risk of respiratory disease in heifers during the first 3 months of life. Prev. Vet. Med. 39:25-37.

Walz, P. H., T. P. Mullaney, J. A. Render, R. D. Walker, T. Mosser, and J. C. Baker. 1997. Otitis media in preweaned Holstein dairy calves in Michigan due to Mycoplasma bovis. J. Vet. Diagn. Invest. 9:250-254.
Wells, S. J., D. A. Dargatz, and S. L. Ott. 1996. Factors associated with mortality to 21 days of life in dairy heifers in the United States. Prev. Vet. Med. 29:9-19.

Williams, D. R., P. Pithua, A. Garcia, J. Champagne, D. M. Haines, and S. S. Aly. 2014. Effect of three colostrum diets on passive transfer of immunity and preweaning health in calves on a California dairy following colostrum management training. Vet. Med. Int. 2014:698741. https://doi.org/10.1155/2014/698741.

Windeyer, M. C., K. E. Leslie, S. M. Godden, D. C. Hodgins, K. D. Lissemore, and S. J. LeBlanc. 2012. The effects of viral vaccination of dairy heifer calves on the incidence of respiratory disease, mortality, and growth. J. Dairy Sci. 95:6731-6739.

Windeyer, M. C., K. E. Leslie, S. M. Godden, D. C. Hodgins, K. D. Lissemore, and S. J. LeBlanc. 2014. Factors associated with morbidity, mortality, and growth of dairy heifer calves up to 3 months of age. Prev. Vet. Med. 113:231-240.

Windeyer, M. C., K. E. Leslie, S. M. Godden, D. C. Hodgins, K. D Lissemore, and S. J. LeBlanc. 2015. Association of bovine respiratory disease or vaccination with serologic response in dairy heifer calves up to three months of age. Am. J. Vet. Res. 76:239-245.

Windeyer, M. C., E. Timsit, and H. Barkema. 2017. Bovine respiratory disease in preweaned dairy calves: Are current preventative strategies good enough? Vet. J. 224:16-17. 